manners, social system, and religion of the Turks, about which a good deal of ignorance prevails among Christians.

Encyclopcedia of Chronology, Historical and Biographical. By R. B. Woodward, B.A., and W. L. R. CATEs. pp. 1487. London: Longmans. 1872.-This is an exceedingly useful work, particularly to those engaged in literary labours. It contains the dates of the chief events in the history of nations, and a record of wars, alliances, and treaties of peace; also the periods of discoveries in the various sciences, with inventions and improvements which have contributed to the advance of civilisation and the increase of the comforts and refinements of life. In the volume will be found likewise notices of the lives of eminent men, with their principal works, literary, scientific, and artistic. We extract one article as an example of the plan of the work:-

"MEAd, Richard, physician,- - y. near London, 1675M.D. Padua, 1695-settles in London, 1696-physician to St. Thomas's Hospital, 1703-F.R S., 1704-M.D. Oxon., 1707lecturer to Surgeons' Hall, 1711-F.R.C.P., Ap. 1716-physician to Geo. II., 1727-ñ. in London, Feb. 15, 1754. Mechanical Account of Poisons, 1702-Dissertation on the Scurvy, 1749-Medicina Sacra, 1748-Monita et Prcecepta Medica, 1751 -edition of Servetus's Christianismi Restitutio, 1723."

In a book of this sort and size absolute freedom from errors is of course unattainable; but so far as we have been able to test it, this Encyclopædia, in respect of accuracy, at least rivals contemporary kindred works. The typography, also, is clear-an important consideration in this much-reading age.

On the Antagonism between the Actions of Physostigma and Atropia. By Thomas R. Fraser, M.D. From the Transactions of the Royal Society of Edinburgh, Vol. XXVI. Printed for the Society by Neill and Co. - Dr. Fraser deserves great credit for this elaborate treatise, which forms a valuable addition to pharmacological literature. The author commenced his researches on the antagonism between the lethal actions of physostigma and atropia in 1868, and the experimental data and views embodied in this work harmonise with what Kleinwachter and Bourneville had previously written. On the subject of nomenclature we will observe that the term "physostigma," applied to the active alkaloid principle of the Calabar bean, is but a modification of the generic name of its botanical source. The experiments were chiefly performed upon rabbits by subcutaneous injection. The general conclusions arrived at from the results of 161 experiments are that atropia prevents the fatal effect of a dose of physostigma by influencing the function of certain structures and producing a physiological antagonism. The work is illustrated by careful diagrams, and altogether it exhibits patient, honest toil, with considerable literary skill.

Natural Philosophy for General Readers and Young Persons. Translated and edited from "Ganot's Cours Elémentaire de Physique" (with the Author's sanction), by E. Arrisrnsor, Ph.D., F.C.S. (Staff College.) London: Longmans. 1872. Abridgments are too commonly mutilations pure and simple, and Dr. Atkinson has done wisely in not adopting suggestions for an abridged edition of his translation of Ganot's "Elémens de Physique," preferring rather to open up a new soil which, having regard to the object to be attained, promised a more satisfactory return for its culture. The "Cours Elémentaire de Physique" has had an extensive circulation in France, and in the English garb provided for it by Dr. Atkinson there is little doubt of its very generally becoming what he designed it to be-namely, "a textbook of physics for the middle and upper classes of boys' and of girls' schools, and a familiar account of physical phenomena and laws for the general reader." In range it claims to represent the amount of knowledge required for the Matriculation examination of the London University.
It is well printed, the illustrations are clearly cut, and for facility of reference all the various sub-divisions are numbered and copiously indexed.

Annual Report of Broadmoor Ciriminal Lunatic Asylum.Broadmoor receives a peculiar class of patients. Of 77 admissions during the year no less than 17 had been charged with murder. The sanitary history of the asylum is also peculiar, and we are therefore disappointed in finding in the report before us little more than a statement of very complicated statistics. Then it is not long since that loud complaints were made against waterclosets, sewers, and sewage irrigation, and a large expense was incurred in substituting earth-closets. It would be particularly interesting now to know with what result. One thing is certain, that the sewerage was shamefully constructed in the first instance, since we find from the report that no less than $7400 \mathrm{ft}$. of drains have been taken up and relaid. Nowonder, under such conditions, that the sewerage was a failure, and that the inmates suffered in their health. Formerly, too, there were acknowledged difficulties in the introduction of the non-restraint management of this extraordinarily dangerous and desperate class, and it would have been particularly interesting to know whether those difficulties have been overcome. We hope that in future reports we may have some further information on these important points.

The Climate of Uckfield in the Weald of Sussex. By C. Lemson Prince, M.R.C.S., Fellow of the Royal Astronomical and British Meteorological Societies, \&c. London: J. \& A. Churchill.-Mr. Prince's book is an olla podrida of meteorological records, weather prognostics, vital statistics, and poetical selections, ranging from Virgil, Pliny, and Aratus, down to the much-abused Dr. Watts. Unfortunately, nothing is said of Uckfield proper-Uckfield as a habitation; and, after perusing the book, the reader will know no more of the place than before, the only guides to the formation of an opinion on the matter being two meagre pictures, one representing "the old bridge at Uckfield," with a solitary cottage at one end, and the other a very primitive little building, which at first sight we should incline to think was a horse-box, but which is in reality the "Uckfield Observatory." However, to those who live in the place the book must have some interest, as the records embrace a period of nearly thirty years.

\section{ON MR. STANSFELD'S PUBLIC HEALTH BILL.} BY HENRY W. RUMSEY, M.D.

Although the Joint Committee of the Social Science and British Medical Associations has not had the advantage of being supported by THE LANCET in their endeavours to obtain certain important amendments in Mr. Stansfeld's Public Health Bill, yet, in more than one leading article, the proposition for County Medical Offeers of Health has been advocated, at least as a reasonable alternative for the Government scheme of mere central inspection. It seems proper, therefore, to place before the numerous readers of THE LaNCET some suggestions for the improvement of that Bill, which, in its present form, is likely to disappoint the hopes of many who have long fought the battle of sanitary reform.

Practically there is very little difference of opinion as to things which ought to be done in every locality. All who have studied public hygiene are agreed upon the necessity of certain fundamental sanitary measures. There may be differences as to details, such as the best method of removing excreta from human habitations, or of preventing the pollution of wells and rivers. But there is no controversy about the propriety of enforcing upon communities 
the obligation to abolish, as far as possible, all causes of preventable disease and excessive mortality.

The real question at issue is-What is the proper local administrative machinery for public-health management?

It can hardly be denied that unless competent, willing, and efficient local administrative authorities are constituted, the difficulties in the path of public sanitation may prove insuperable. It is also well known that the very machinery created by the Public Health Act, 1848, Local Government Act, 1858, and Sanitary Act, 1866, with their numerous amendments, has, in a large number of localities, raised up serious impediments to the progress of improvement, and to the general enforcement of sanitary reforms. To confirm that administrative machinery on a grander scale, as now proposed by Government, would be a fatal mistake, establishing more firmly obstacles which hereafter would be almost irremovable. We have had, during the last thirty or forty years, quite enough of blundering legislation and defective organisation, ending in a chaos of inoperative laws and conflicting authorities.

Now it is on the administrative question that we have the misfortune to differ with both the Royal Sanitary Commission and the Local Government Board. With regard to the former, our arguments have been stated at length in the Report of the Joint Committee on that of the Royal Commission-arguments which I believe have never been fairly met, and which certainly have never been refuted; whilst our report has been generally accepted by sanitarians, especially in the provinces, as indicating the true principles on which this question should be settled. With regard to the latter, our recent memorial to Mr. Stansfeld has pointed out the main defects and shortcomings of the Government measure, and suggested the principles, even an outline of the methods, by which existing authorities might be modified so as to secure the objects of sanitary legislation.

From the first we have regarded the medical officers of the Poor-law unions, the registrars of births and deaths, and the public vaccinators, as necessary elements of any organisation for purposes of public health. The work done by the medical officers, and especially that which they may have to do when a proper registration of sickness attended at the public expense shall be established, is truly sanitary work; indeed, it supplies the scientific foundation for all sanitary measures. Therefore, the local authorities in this department-viz., the boards of guardians, in so far as they administer medical relief, or require sanitary reports and sickness returns, or make arrangements for vaccination and registration (to say nothing of their functions as to nuisances and disinfection) - are truly sanitary authorities, and as such they must be dealt with in any Public Health Bill.

Although we have objected, for very good rea sons, to place the Poor-law medical officers in the position of the sole officers of health in their respective districts, we have acknowledged as plainly as the Royal Commission the necessity of their well-ordered co-operation. Moreover, we have objected to the recommendations of the Commission on this ground among others-that they made no provision for the joint action of the boards of guardians with the local bodies in towns and districts under the Local Government Act, which are required to carry into effect other sanitary measures. Yet Mr. Stansfeld, on the authority of the Commission, proposes to compel all these numerous local boards to appoint medical officers of health, who may or may not be Poor-law medical officers, but who, at all events, would require the systematic and legalised aid of the Poor-law Department.

In our report on that of the Commission, especially in sections 12, 13, and 14, we showed the error of maintaining the division of sanitary functions between these two kinds of local authority, and the absurdity of that duplication of authority at the extremities of the system which the Act of last session has abolished at the centre, and which has the effect of placing every Poor-law medical officer in towns under two masters, as well as of dividing the responsibility of hospital provision between two boards. We urged accordingly "the universal comprehension of all the various subjects of sanitary administration within the same district,"-that is to say, the consolidation or unification of local sanitary authority, a point theoretically admitted, but practically ignored, by the Royal Commission.

Again, in our recent memorial, we protested against both the existing and the proposed future duplication of autho- rity ; and the first of our final recommendations pointed out the method by which local sanitary administration might be consolidated.*

I am prepared for the reply, that the President of the Local Government Board may take sufficient powers to compel the guardians and the local boards, or at least their respective officers, to work together for certain purposes,a power which, as Mr. Stansfeld intimated, "does not appear on the face of the Bill." But we can only judge of the measure as it appears. We can accept of no understandings or possibilities which are not authorised by the letter of the Act. Unlimited and unknown powers "taken" by a central authority from which there is no appeal, are intolerable to Englishmen. The powers of interference and coercion conferred by the Public Health Bill upon the Local Government Boara far exceed anything of a compulsory kind proposed by those who want unification of local authority. The fact is that we do not desire to touch the powers of local boards and town councils as to any of the inatters which they administer under the Public Health and Local Government Acts, except perhaps those which belong to the drainage area, or other matters for which Mr. Stansfeld himself contemplates united action. On the plan sketched out in our recent summary the towns would remain intact. We simply propose that for certain purposes common to them with adjacent or co-existent authorities, the town boards should be required to co-operate with the boards of guardians.

It is plain that such combination of authority would increase the powers of " urban" authorities by giving them the influence they ought to possess in the administration of medical relief, in the provision of hospital accommodation, in medical visitation of houses and places, in sanitary reports, in arrangements for vaccination and disinfection, as well as in the registration of mortality and sickness and the causes thereof.

On the mistaken hypothesis that we wish to interfere with local government, it has been assumed that the towns would vehemently resist any proposal to give them powers of co-operation with boards of guardians. But I believe the reverse to be the fact; for inquiries in several places lead to the conclusion that such additional powers would not be at all unacceptable to town authorities.

Proceeding on the principles now defended, the first amendment in Mr. Stansfeld's Bill should be made in Clause 4, for which, and for parts of Clauses 5 and 6, the following might be substituted :-

(A) "From and after, \&c.......the unions (or registration districts) of England and Wales shall constitute the local sanitary districts, and shall be respectively subject, in certain matters, to be determined by the Local Government Board, to the jurisdiction of authorities to be called District Councils. Every such District Council shall be composed partly of elected members of urban authorities, hereinafter mentioned, and partly of elected guardians of the union, and partly of ex officio guardians. The number of members to be chosen by each urban authority within the union, and the number to be chosen by the board of guardians, and the number of ex officio members shall be determined by an order of the Local Government Board, which order shall also define the purposes for which the said District Council is formed, and shall contain regulations as to the qualification of members of the District Council, as to the mode of their election, as to their continuance in office, as to casual vacancies in the District Council, as to its meetings and officers, and any other matter or thing with respect to which the Local Government

Board may think fit to make any regulations, \&c."

The above clause would of course render necessary some alterations of subsequent clauses. It has these obvious advantages: it would leave each urban authority intact as to matters which are not common to the whole union; whilst it would commit to the District Council all general matters-such as medical service, sanitary inspection, disinfection, vaccination, and the registration of birtbs, deaths,

"We accept, provisionally, the registration district as the unit of area, subject to future correction of limits in conformity with revised count boundaries; and we ask that every town or local board district included in a registration district may be enabled and required to act with the board of guardians by a juint committee, as the local authority for sanitary and medical purposes." 
and sickness, - as well as such matters as are mentioned in Clause 16, par. 2, under "general expenses." The "special expenses" (see par. 3 of the same clause) would be those which specially concern the towns, as paving, lighting, scavengering, \&c. The drainage of the whole area should be under the District Council; whilst the expenses thereof incurred in each local-board district or town would be "special," and as such charged to each as a "contributory place" (see Clause 16). Every part of the count! $y$ would thus secure a more extensive, and therefore a better, if not a perfect, drainage area; and the Local Government Board would still be able to combine "sanitary districts" for this or other purposes mentioned in Clause 25.

By means of a "District Council" for the whole union we should obtain the advantage of a single authority, containing valuable town elements, for the administration of medical relief, the organisation of dispensaries, the provision of hospitals, vaccination, and other matters of preventive medicine; we should also have the benefit of complete unification of all medical, statistical, and inspectorial arrangements within a well-known and established boundary.

The "table" of urban authorities might remain as in the Bill, merely transposing the columns and omitting the word "sanitary" in the headings.

I would now call attention to the proposed "port autborities":-Clause 19 constitutes "any sanitary authority," \&c., or "any conservators," \&c., the sanitary authority over the whole port. The necessary combination of autborities is here evidently wanting. What is required for ports is that all the authorities connected with the port should be brought to act together. Thus, the autbority wbich appoints medical officers and registrars, and every sanitary authority whose district abuts on the port, as well as every adjacent district called "riparian" in the Bill, should be combined for the purposes of a port anthority. This, I believe, cannot be effected under Clause 19, as it now stands, although Clause 20 seems to assume that the so-called "riparian" authorities are to be treated as "contributory places." It ought to be made quite clear that, for port purposes, the several authorities concerned are to be united; and this the clanse does not do. The principle of "contributory places" is so excellent that Mr. Stansfeld might have adopted it to a greater extent. It is this principle in Clause 16 which puts an end to "special drainage districts" and makes this Bill so far an improvement upon Sir C. Adderley's. Let him carry the principle a little further, and it would be rarely if ever necessary to form a new Local Government district.

With regard to the 25 th and following clauses for the " union of districts," if not superseded by the establishment of county boards, an amendment is required to the effect that the districts to be united shall be contained in the same county; and that where any sanitary district (not being under an urban authority) adjacent to the intended united district, is situate in more than one county, those parishes which belong to the same county as the united district should be dealt with according to their gross rental as proposed by Mr. Knatehbull Hugesson in 1869-that is to say, either formed in to a separate sanitary district or annexed to an adjoining district, rearly for combination with the aforesaid united district. Any single parish divided ly a county boundary would belono, by the same clause, to that county which comprises the greater part in value (or area) of such parish. The same provision would apply to boroughs or local-board districts situate in more than one county. A further provision would be required to enable united districts on opposite banks of ans river which forms a county boundary to combine for purpeses of river conservancy only.

Clause 25 should then be amended as follows:-

(B) "When it appears to the Local Government Board that it would be to the improvement of the publio health and to the arvantage of any sanitury districts situate in one county to be formed into a united district for any purnoses of the Sunitary Acts, the said Local Government Board may, by a provisional order, form such districts into a united district."

But a combination of districts for the sole purpose of appointing a principal merical officer of health ought not to require the trourlesome frrmality of a provisional order.

Clauses 26 and 27 would also have to be amended, so a to empower the county justices to aid in the formation of unions of districts.
Those who have followed me thus far will see that the question still remains, whether it were better to accept Mr. Stansfeld's provisions for the union of districts, or to make a further effort to obtain county boards. If the Public Health Bill is to pass during this sessinn, it might suffice to endeavour to amend, as proposed, Mr. Stansfeld's clauses, so that his united districts night not bereafter interfere with a more complete county organisation.

But if sanitary legislation be unavoidably postponed until 1873-not an improbable event, -it would, in the opinion of many, be wiser to move for the adoption of a series of clauses, very ably drawn up by Mr. Michael, the barrister and one of the secretaries of the joint committee, for the formation of county sanitary boards.

That county administrative boards, containing a representative element, will be established within a few years, is almost certain. Greatly will such a measure, if wisely contrived, redound to the honour of any Ministers who may carry it through Parliament and at the same time succeed in barmonising the long existing conflict between county and parochial (or Poor-law) jurisdictions, by providing for a mutual adjustment of their respective boundaries.

The acknowledged advantages of a far more extensive area, not only as regards many great sanitary undertakings and the wider objects of administration, but also as affording means and opportunities of obtaining a higher and more adequately salaried class of officers, may be claimed hy united districts almost to the same extent as by counties. But the main arguments for the county versus the united district may be stated thus briefly :-

1. The present administraturs of counties-justices of the peace-are an essential element in the coniposition of any new provincial authority having a superior jurisdiction to that of the ordinary sanitary district. The county magistracy, as a body, are comparatively free from trading in. terests, corrupt bias, and political party influence; and, being for the most part well-informed gentlemen, their decisions carry a weight which can never belong to the minor elective boards. There is no body in provincial society on whom the public rely for ability and independence more than on the justices in sessions; while, as representing the property as well as the intelligence of the shire, they are sufficiently averse to any needless or extravagant outlay.

2. The county justices already exercise many important functions connected with the public health, and are therefore sanitary authorities. For example: (a) T'hey visit, and appoint visiting physicians to hospitals for the insane. (b) They regulate the sanitary condition of the inmates, not only of those asylums, but also of prisons, reformatories, and other corrective establisbments. (c) They carry into effect, with great vigour and success, measures against the contagious diseases of cattle, intimately connected with human pathology. (d) They regulate and pay for coroners' inquests to ascertain the cause of death, a most important item of sanitary inquiry. (e) They appoint engineers or surveyors for public works, and have to do with river conservancy as far as bridges are concerned. And $(f)$ they are empowered to appoint analysts, to check adulteration of food and impurity of water-supply. Now, as they perform these duties with satisfaction and benefit to the public, they are not likely to be deprived of their powers by Parliament. Why not invest them with other functions of sanitary administration?

3. If another kind of superior local authority, such as Mr. Stansfeld's "Joint Boards," be constituted in areas having no relation to counties, and perhaps including parts of more than one county, and be empowered to execute other sanitary duties, there will result a duplication of sanitary authority in wide and uncontormable areas, thus establishing a new source of confusion in local and county government.

4. Mr. Knatchbull Hugessen's Bill of 1869, as well as Mr. Guschen's of 1871, provided f $(r$ representative county government, although, perhaps, not on the best principle. At all events these measures showed how the county area might be further utilised for purposes of local administration. Why not at once take that area for a combination of local sanitary authorities with the magistracy?

5. We should then possess a suitable Court for the appointment of county officers of health, thus diminishing very properly the hyper-centralisation of the present Bill.

There is a difficulty, as we all know, arising from the 
irregularity of county boundaries. But this is anything but an insuperable difficulty. A general revision of districts and boundaries might be safely committed to county authorities, subject to the control of the Local Government Board.

If the claims of the county be established as an area for the higher purposes of sanitary administration, it might be advisable, in default of county boards formed on the elective principle, to propose the following clauses for insertion in the Public Health Bill, in place of Clause 11, and of all in Clause 13 which relates to medical officers of health.

(C) "Until such time as, by Act of Parliament, county boards shall be established for the purpose of administering the affdirs of counties, a county authority for the purposes of this Act shall mean the justices of the peace of a county, or of any riding, division, or part of a county having a separate commission of the peace, except as in hereinafter provided. And such county autherity, in quarter or special sessions assembled, shall, fom time to time, appoint a (principal) medical officer of health, or more than one such officer if the population exceed 250,000 , or if required by the Local Government Board. If more than one such officer be so required, such county, or part of a county, shall be divided by the county authority into so many districts as there are to be medical officers of health; every such scheme of division being subject to the approval of the Local Government Board."

Although, under the administration of county magistrates, there would be less necessity for providing that the appointment to, and removal from, office, should be subject to this approval of the Local Givverument Board, it is, nevertheless, considered important that Parliament should sanction this principle, and, therefore, I recommend its adoption, together with the following provisions:-

(D) "The Local Government Board shall issue regulations, by a general order, respecting the duties and qualifications of medical officers of health. Every principal medical officer of health shall devote his whole time and attention to the duties of his office. He shall report to the county authority, and to the several local sanitary authorities within the district to which he is appointed, on all matters concerning the public health, and on all causes of disease and degeneracy which may come under his notice; and he shall afford advice and aid to all such sanitary authorities. His salary, with reasonable allowance for a clerk and for travelling expenses, shall be fixed by the county authority, subject to the approval of the Local Government Board, and shall be charged half to the county rate and half to the Consolidated Fund."

To meet the case of existing appointments in provincial towns, I wculd suggest that, wherever a medical officer of health is appointed by the local sanitary authority, under the provisions of a local Act or of the Public Health Act 1848, and with the sanction of the Local Government Board to the terms and conditions of such appointment, every such place be exempted from contributing to the County Rate in respect of the salary of the county medical officer; and that every statutory obligation to appoint a medical officer of health, except on the same conditions as are required for county officers of health, be repealed.

Some such clause as the following should be substituted for Clause 13 of the Public Health Bill :-

(E) "In all places where a medical officer of health is not appointed by the local authority, the district medical officers of unions shall be required to assist the county medical officer of bealth, by reporting to him all such facts relating to sickness and mortality, and the supposed causes thereof, and by performing such duties of a preventive nature as may be directed by the Local Government Board, and every such district medical officer shall be properly remunerated for such duties on a scale approved by the Local Government B ard."

It should indeed be made imperative on all District Councils to appoint deputy or assistant officers of health, who would of course be medical practitioners, whether under the Poor Law or not.

But no counter-propositions or arguments have shaken our conviction that, in the interests alike of the public and of the profession, all health-officers who do not take the position of deputy or assistant, that is, all the principal medical officers of health, whether in counties or in firstclass towns, should be required to surrender their entire time and effort to their official duties, and be remunerated accordingly. There may be some places, desirable as local centres of sanitary advice, in which, owing to the sparsity of the surrounding population, it might be expedient that the Local Government Board should be authorised to permit the principal officer of health to attend in consultations, or to hold office in public institutions; but all such cases should be reported to Parliament, with the grounds for the exceptional permission.

The appointment of a principal officer on the preceding conditions should be compulsory on towns exceeding a quarter of a million of population; and even for towns not so vast the local and county authorities might be authorised to annex a number of adjacent sanitary districts, sufficient to render the officer independent of private practice. Whatever may be the precise conrse taken with regard to provincial organisation, every effort should be made to prevent the enactment of that most objectionable and fallacious clause of the Pablic Health Bill which makes it compulsory on every little local authority to appoint a full officer of health.

I am constantly receiving remonstrances on this point from eminent persons, medical and others, in different parts of England. I may quote from three letters very recently received.

(1) From an active and philanthropic magistrate in the northern counties:- "I don't expect any good from $\mathrm{Mr}$. Stansfeld's proposition for health officers, and a move in the wrong direction would be simply mischievous. To appoint the Poor-law doctors, from my experience of the article, without a superior offeer, will convert the whole business in to a farce."

(2) From a distinguished provincial surgeon and an original investigator of the exanthemata:- "I am quite sure that without county arrangements no really efficient sanitary measures can be carried out."

(3) From a University Professor of great repute in matters of health:- "I hold that it is the duty of the State to avoid multiplying the number of cases in which a man's private interests are likely to tempt him to transiger or tamper with his sense of duty to the public. There will always be plenty of temptations of this kind, do what we will. Legislation is immoral which makes them more numerous than they must necessarily be, or which creates such opposition and antagonism de novo. With how much force does this enunciation of one of the most ordinary principles of human action apply to the using Poor-law medical officers as health officers."

If Mr. Stansfeld persists in this project, contrary to the weight of authority and experience, he will alienate the support of the best men in the country. I am aware that he might reply that he was supported by the five medical members of the Royal Commission. My rejoinder would be that four out of the five have little, if any, personal experience of the provincial districts of England, and that the only one who does practically know them is at issue on this point with, I believe, every other provincial member of the very numerous and influential Committee on State Medicine, of which that gentleman was once chairman, and which procured the appointment of the Royal Commission.

Only a few words more. The distinction between principal and deputy in the health-officer appointment is not merely nomiual, as $\mathrm{Mr}$. Stansfeld seems to think. It recognises and provides for a real and a two fold necessity : first, the necessity for constant and ascurate observation and report of facts by those engaged about the dwellings and the sickness of the people, aud this is the deruty's office; secondly, the necessity for superior special knowledge in making the best use of that information, and of impressing it at once upon local authrities, with that offeial independence which gives weight to opinion and force tu advice, and this is the principal's offee.

I have prepared some clauses relating to returns and regristration of sickness, biths, deaths, ard the causes of deaths, with provisions for inquire iuts uncertified deaths, and unsatisfactory certificates and returns, and for payment for sickness returns and sanitary reports, \&c. \&c. These clanses I may offer for publication in a future number.

Cheltenham, May 22nd, 1872. 